\title{
Total Liberation: The Power and Promise of Animal Rights and the Radical Earth Movement By David Naguib Pellow
}

\section{Minneapolis, MN: University of Minnesota Press, 336 pp., 2014 ISBN: 0816687773}

\author{
Reviewed by Kimberly Murray ${ }^{1}$
}

One problem facing sociologists is the study of intersectionality and the ways that group memberships intersect to create different realities for groups and individuals (Crenshaw, 1994). Although many attempts are made to understand prevalent variables of interest (i.e., race, class, gender, and sexual orientation), studies often become focused on one variable of interest, while giving other variables less attention. Research on intersectionality also lacks a complex understanding of the relationships between humans, the environment, and other nonhumans. These relationships have yet to gain prominence in mainstream sociological discourse, and a need remains for a theoretical framework that incorporates an understanding of natural resources, animals, and ecosystems as central and necessary to the study of society. Similarly, sociologists must endeavor to prevent the compartmentalization of sociological thought into different areas of interest, with some areas of interest gaining more attention than others.

David Naguib Pellow's Total Liberation: The Power and Promise of Animal Rights and the Radical Earth Movement is one attempt to demonstrate the intersectionality of human and nonhuman life. He outlines the "total liberation framework," which builds upon many theoretical perspectives to develop a new understanding of inequality across all life forms. This framework acknowledges not only oppression across key variables, such as race, class, and gender, but also across nonhuman entities. He argues that we cannot fully understand oppression within the confines of human societies, nor within the environments in which we live. He invites readers into the lives of members of the total liberation

1 University of Oklahoma, United States. 
movement, including animal and earth liberationists, through an intense and meticulous analysis of more than 100 interviews, observations of events and rallies, and material culture produced by liberation groups.

The total liberation framework has four key components around which the book is organized: "an ethic of justice and anti-oppression for people, nonhuman animals, and ecosystems; anarchism; anticapitalism; and an embrace of direct action tactics" (p. 61). The book first investigates the origins of radical thought found within animal and environmental movements (Chapter 1). The following chapters (2-4) address the cultural value of justice within these movements, anarchism and anticapitalism, and direct action taken by members of the movement. The last two chapters (4-5) address the Green Scare and the ways in which members of these radical movements have resisted governmental repression by modeling tactics found within other collective movements, such as women's suffrage and abolitionist movements. The chapters form a powerful argument that one cannot study society without considering the natural environment, and that the exploitation of nonhuman life is just as destructive, and perhaps even more damaging, as inequality found within human societies. What makes each chapter so interesting and valuable to both the public and academia are the candid excerpts from interviews with liberationists.

Total Liberation also adds to the body of work on collective movements, violence and conflict, and framing. Even though environmental harm has increased over time, the American cultural consciousness largely prioritizes and rewards economic, rather than environmental, endeavors. Environmental concerns may fade from the American consciousness because of the ways in which environmental movements develop (Burns \& LeMoyne, 2001). Environmental concerns are often included within a political regime. However, political regimes have not prioritized environmental protection, which has led to less effective environmental policy.

Similarly, Homer-Dixon (1999) describes the relationship between environmental scarcity and social unrest, violence, and conflict. Violence often occurs when some other variable (such as class inequality or racial oppression) exists along with environmental scarcity. This creates a complex mix of stresses that increases likelihood of violence, which is predicted to increase as the world's resources continue to be consumed in unsustainable ways.

Pellow does an excellent job contextualizing the total liberation movement as a product of the political and economic inequality surrounding environmental concerns and the individuals fighting to change the American consciousness to understand ecosystems and other nonhuman life forms as entities that need rights and protections comparable to the rights people aspire to attain. Finally, Benford and Snow (2000) argue that before the 1980s, social movements' 
scholars failed to fully address in their studies "meaning work - the struggle over the production of mobilizing and countermobilizing ideas and meanings" (p. 613). Social movement scholars seeking to understand meaning work must first acknowledge that actors in social movements are actively involved in producing new meanings or challenging, changing, and maintaining existing meanings within a culture. Pellow captures the negotiation of meanings about different world views pertaining to the relationship between nature and society, and outlines, especially in Chapter 1, "injustice frames" (Gamson et al., 1982) developed by members of liberationist groups.

Although the book has many contributions to the literature, including a summary of various socioecological theories on the relationship between animals, nature, and society and an examination of the meaning of terrorism when the terrorist label is placed upon members of liberationist groups such as the Earth Liberation Front and the Animal Liberation Front, one of the most important takeaways from the book relates to the political nature of race. Pellow argues that most radical earth and animal rights liberationists are privileged in that they are white and middle-class, yet they reject the idea of white privilege. In a way, they become "less white" in their defiance, and they are placed within a hierarchy of oppression typically reserved for racial minorities. Also, despite arguing that white liberationists are able to ideologically reject white privilege, he points out the advantages white liberationists have, such as shorter prison sentences and larger public support. Therefore, even though race is socially constructed, varies across time and place, and is a political tool used to create a system of superiority and inferiority within society, it seems as if within the American cultural context, one cannot fully separate the idea of race and skin color. This presents readers with a conundrum: white liberationists are not fully "white" in that they reject their superiority within the racial hierarchy, yet they still have advantages within the criminal justice system compared to racial minorities because of their whiteness. Theoretically, the study of race and how racial labels apply to whites who reject their privilege or do not fully achieve "whiteness" (i.e., poor whites) is understudied, making Pellow's insights highly valuable.

Perhaps one of the most important contributions of this book that all academics can benefit from is Pellow's description of his research process and the ethical concerns he faced. While researching animal and earth liberationists, he faced pressures from nonacademic authorities to divulge confidential names of interviewees suspected of illegal or ecoterrorist activities. He highlights a huge problem facing academics: the need to conduct research in a way that ensures the confidentiality of participants, even when pressured by powerful government agencies to share confidential information. He was approached by the FBI, sought advice from lawyers about how to protect the participants in 
his study, and even used email addresses not associated with his university in order to protect his participants. He describes how another professor was jailed because he refused to give access to confidential information to authorities. Pellow openly acknowledges that he received "mixed messages" from the American Sociological Association on the matter, but for personal and professional reasons he refused to cooperate with the authorities. Academics must discuss these issues and determine better ways to protect researchers and research participants from negative consequences.

Finally, this book advances what Bergesen and Bartley (2000) describe as an "ecosociology," a discipline that recognizes the need for sociologists to think beyond purely social boundaries in order to incorporate all living things into theory. "The key is the ecoequality assumption, for once it is recognized that all living things have the same moral status, then it is impossible to leave nonhumans out of the conception of a moral community and some kind of social order" (p. 318). Pellow depicts liberationists in a much more positive light than government agencies and the media often portray them. It is important also to understand that liberationists view their actions as just, despite the risk of being labeled a terrorist. Amster (2006) argues that previous attempts to extinguish the cause of environmental and animals rights activists by government or political lobbies often encouraged more deviant and violent behavior. Therefore, by eliminating proper and democratic modes of expressing frustration and disagreement with the capitalist world view, members of these movements are left with few options and resort to extreme acts in order to be heard.

\section{References}

Amster, R. (2006). Perspectives on ecoterrorism: Catalysts, conflations, and casualties. Contemporary Justice Review: Issues in Criminal, Social, and Restorative Justice, 9(3), 287-301.

Benford, R. D., \& Snow, D. A. (2000). Framing processes and social movements: An overview and assessment. Annual Review of Sociology, 26, 611-639.

Bergesen, A. J., \& Bartley, T. (2000). World-system and ecosystem. In T. D. Hall (Ed.), A world-systems reader: New perspectives on gender, urbanism, cultures, indigenous peoples, and ecology (pp. 307-322). Lanham, MD: Rowman \& Littlefield Publishers.

Burns, T. J., \& LeMoyne, T. (2001). How environmental movements can be more effective: Prioritizing environmental themes in political discourse. Research in Human Ecology, 8(1), 26-38. 
Crenshaw, K. (1994). Mapping the margins: Intersectionality, identity politics, and violence against women of color. In M. A. Fineman, \& R. Mykitiuk (Eds.), The public nature of private violence: The discovery of domestic abuse (pp. 93-118). New York: Routledge.

Gamson, W. A., Fireman, B., \& Rytina, S. (1982). Encounters with unjust authority. Homewood, IL: Dorsey.

Homer-Dixon, T. F. (1999). Environment, scarcity, and violence. Princeton, NJ: Princeton University Press. 
This text taken from Human Ecology Review Volume 21, Number 1, 2015, published 2015 by ANU Press, The Australian National University, Canberra, Australia. 